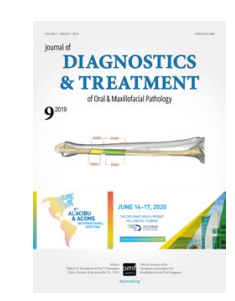

Guest Editorial

\title{
Can an Article Processing Charge Reach the Number of Impact Factor 3.825?
}

\author{
Daniel Robles Cantero ${ }^{a}$, Kateryna Y. Nagorniak ${ }^{b}$ \& Ivan V. Nagorniak
}

Exciting and important papers are often published in journals with high impact factors. ${ }^{1}$

-Inder M. Verma

Editor-in-chief, Proceedings of the National Academy of Sciences

Dental implants and their role continue increasing not only in oral surgery/periodontics but also in fibula jaw surgery. ${ }^{2}$ So, the critically important dental implants sections in oral and maxillofacial surgery journals are growing similar to publications focused clearly on implants. One of them is Clinical Oral Implants Research (COIR), which is a 'hybrid' journal (contains both, toll and open access articles) ${ }^{3}$ and official publication of the European Association for Osseointegration published by John Wiley \& Sons Ltd. ${ }^{4}$ Being launched in December 1990 (Niklaus P. Lang is a founding editor) as quarterly journal, it continues developing nearly full last 30 years. From 1997 it increased frequency to 6 issues per year and from 2008 started circulate 12 issues per year.,

SCImago Journal \& Country Rank put COIR at first place among 47 journals in category "Oral Surgery." According to ISI Journal Citation Reports Ranking

a DDS, MSc, Clinical Director of Miguel de Cervantes European University, Co-director in Master of Periodontology and Implantology of UEMC. Private Oral Surgery Practice, Madrid, Spain.

E-mail:drobles@clinica.uemc.es

${ }^{b}$ PhD Student, Department of Therapeutic Dentistry, Stomatology Institute, Shupyk National Medical Academy of Postgraduate Education, Kyiv, Ukraine.

c Oral Surgeon, PhD; Private Dental Practice, Kyiv, Ukraine.

E-mail: ivan.nagorniak@gmail.com

https://dx.doi.org/10.23999/j.dtomp.2019.9.3.

(C) 2019 OMF Publishing, LLC. This is an open access article under the CC BY license (http://creativecommons.org/licenses/by-nc/4.0/). in 2018 the journal holds fifth position among 90 publications in category "Dentistry, Oral Surgery and Medicine" and fourteenth place among 80 journals in category "Engineering, Biomedical." $A$ journal's 2018 impact factor (IF) is at a very prestigious mark and reached 3.825. ${ }^{4}$ And it's very interesting that article processing charge (APC) in August 2019 is also very close to the number of journal's IF, being at level of USD 3,800 (Table). ${ }^{8}$ So, in that case, such a high APC can be named as 'price of prestige.'

TABLE. Comparison of Impact Factor and Article Processing Charge in Journal Clinical Oral Implants Research.

\begin{tabular}{|c|c|}
\hline $\begin{array}{c}2018 \text { Journal Impact } \\
\text { Factor }\end{array}$ & $\begin{array}{c}\text { Article Processing } \\
\text { Charge }\end{array}$ \\
\hline 3.825 & USD 3,800 \\
\hline
\end{tabular}

There is ongoing debate among publishers about the level of APC., ${ }^{9}$ And we know that some journals have APC even at the level of USD 6,000, excluding tax. ${ }^{11}$ But, can the APC can be as high as COIR has? Our opinion is yes and the example of COIR proved that. As high APC will give a publisher a wide range of possibilities: to appoint the honorary salaries for editors/reviewers, to spent more income for advertising, growing projects (journal club, podcasts, etc.) inside the journal, organizing awards with stipends for young generations of authors, thus moving the specialties forward.

Impact factor: Imperfect but not yet replaceable. ${ }^{12}$
-Stuart Brody
Professor, University of the West of Scotland 


\section{REFERENCES}

1. Verma IM. Impact, not impact factor. Proc Natl Acad Sci USA 2015;112:7875-6; https://doi.org/10.1073/ pnas.1509912112.

2. Attia S, Wiltfang J, Pons-Kühnemann J, Wilbrand JF, Streckbein P, Kähling C, Howaldt HP, Schaaf H. Survival of dental implants placed in vascularised fibula free flaps after jaw reconstruction. J Craniomaxillofac Surg 2018;46:1205-10. https://doi. org/10.1016/j.jcms.2018.05.008.

3. Robles Cantero D, Schoenbaum TR, Zhehulovych ZY, Nagorniak IV, Fesenko II. Comparison of article processing fees on open access journals with a 4.5-year history of publishing. J Diagn Treat Oral Maxillofac Pathol 2019;3:176-85.

4. Clinical Oral Implants Research: home [document on the internet]; 2019 [cited 2019 Sep 06]. Available from: https://onlinelibrary.wiley.com/journal/16000501.

5. 1997 - Volume 8, Clinical Oral Implants Research [document on the internet]; 2019 [cited 2019 Sep 03]. Available from: https://onlinelibrary.wiley.com/ loi/16000501/year/1997.

6. 2008 - Volume 19, Clinical Oral Implants Research [document on the internet]; 2019 [cited 2019 Sep
05]. Available from: https://onlinelibrary.wiley.com/ loi/16000501/year/2008.

7. SCImago Journal \& Country Rank: journal ranking: oral surgery [document on the internet]; 2019 [cited 2019 Sep 09]. Available from: https://www.scimagojr. com/journalrank.php? category $=3504$.

8. Wiley article publication charges for OnlineOpen journals [document on the internet]; 2019 [cited 2019 Sep 06]. Available from: https://authorservices. wiley.com/asset/Wiley-Journal-APCs-OnlineOpen. xlsx.

9. Green T. Is open access affordable? Why current models do not work and why we need internet-era transformation of scholarly communications. Learn Publ 2019;32:13-25. https://doi.org/10.1002/leap.1219.

10. Van Noorden R. Open access: the true cost of science publishing. Nature 2013;495:426-9. https://doi. org/10.1038/495426a.

11. Elsevier: about: open access [document on the internet]; 2019 [cited 2019 Sep 03]. Available from: https://www.elsevier.com/about/open-science/openaccess.

12. Brody S. Impact factor: imperfect but not yet replaceable. Scientometrics 2013;96:255-7. https:// doi.org/10.1007/s11192-012-0863-x. 